\title{
Effect of Retorque on Loosening Torque of Prosthetic Screws Under Two Levels of Fit of Implant-Supported Dentures
}

\author{
Aloísio Oro SPAZZIN ${ }^{1}$ \\ Guilherme Elias Pessanha HENRIQUES ${ }^{2}$ \\ Mauro Antônio de Arruda NÓBILO ${ }^{2}$ \\ Rafael Leonardo Xediek CONSANI ${ }^{2}$ \\ Lourenço CORRER-SOBRINHO ${ }^{1}$ \\ Marcelo Ferraz MESQUITA ${ }^{2}$ \\ ${ }^{1}$ Department of Restorative Dentistry, Dental Materials Division, Piracicaba Dental School, \\ State University of Campinas, Piracicaba, SP, Brazil \\ ${ }^{2}$ Department of Prosthodontics and Periodontics, Piracicaba Dental School, \\ State University of Campinas, Piracicaba, SP, Brazil
}

\begin{abstract}
This study evaluated the influence of retorque on loosening torque $(\mathrm{Lt})$ of prosthetic screws in implant-supported dentures with different fit levels. Ten mandibular implant-supported dentures were fabricated and then 20 cast models were then prepared using prosthetic structures to create 2 fit levels: passive fit (Pf) and misfit (Mf). Two tightening techniques were also evaluated: initial torque only (T1); and initial torque and retorque after $10 \mathrm{~min}$ (T2). Gold or titanium screws were used, resulting in 4 groups to each one: $\mathrm{Pf} / \mathrm{T} 1, \mathrm{Pf} / \mathrm{T} 2, \mathrm{Mf} / \mathrm{T} 1, \mathrm{Mf} / \mathrm{T} 2$. The Lt was measured $24 \mathrm{~h}$ after the tightening torque using digital torque meter. Data were analyzed statistically by two-way ANOVA and Tukey's test $(\alpha=0.05)$, separately for each screw material. For titanium screws, no significant difference $(\mathrm{p}>0.05)$ was found between $\mathrm{Pf} / \mathrm{T} 1$ and $\mathrm{Pf} / \mathrm{T} 2$, or between Pf/T2 and Mf/T2. However, statistically significant difference $(\mathrm{p}<0.05)$ was found between Pf/T1 and Mf/T1, and between Mf/T1 and Mf/T2. Mf reduced the Lt using T1, while and T2 increased the $\mathrm{Lt}$ for Mf. Retorque and fit were shown to have no significant influence on the Lt of the gold screws. Retorque application made insignificant the misfit effect on the Lt of the titanium screws, suggesting that this procedure should be performed routinely during the screw tightening in multi-unit dentures.
\end{abstract}

Key Words: implant prosthesis, misfit, retorque, prosthetic screw, loosening torque.

\section{INTRODUCTION}

Lack of passivity of implant-supported dentures may cause biologic complications of the surrounding tissues, or mechanical failures of the dentures and implant systems. Biological complications may include adverse tissue reactions, pain, tenderness, marginal bone loss, and loss of osseointegration (1). Nevertheless, it has been shown that osseointegrated implants have some biologic tolerance for certain levels of misfit $(2,3)$.

Mechanical complications may include loosening of the prosthetic and abutment screws or fracture of various components in the system (1). Instability or loosening of prosthetic screws is frequently reported complications in dental implant therapy $(4,5)$. Although screw loosening per se is not a complication, it may induce more serious complications to others components (6).

Professionals or patients do not perceive the loosening of one screw in multi-unit dentures, which implicates overload on another screw that can also loosen. These ongoing sequences may favor the occurrence of failures, resulting in component fractures or

Correspondence: Dr. Aloísio Oro Spazzin, Departamento de Odontologia Restauradora, Área de Materiais Dentários, Faculdade de Odontologia de Piracicaba, UNICAMP, Avenida Limeira, 901, 13414-903 Piracicaba, SP, Brasil. Tel: +55-19-2106-5345. Fax: +55-19-2106-5218. e-mail: aospazzin@yahoo.com.br 
loss of bone tissue surrounding the implants that still have tightened screws, due to overload of stress on the screw joints and bone-implant interface. The literature suggests that in addition to the lack of passivity of dentures, several factors can contribute to screw instability, namely insufficient tightening torque (7), biomechanical overload (8), differences in screw material or design (9) and screw settling $(10,11)$.

When a certain torque is applied to a screw, the energy is expended in smoothing surface irregularities for maintaining the surfaces together. After thread engagement, surface asperities are flattened and additional input torque is applied toward elongation of the screw and generation of preload (12). Siamos et al. (11) evaluated the effect of retightening some time after initial tightening torque on the joint stability of the abutment screws, suggesting an easy and fast method to increase the joint stability.

The screw joint between implant and machined abutment is in passive state after the torque applied to the screw. The forces created within the screw joints in the passive state are the clamping forces and preload only (13). Multi-unit implant-supported dentures do not present a perfect fit (14), thus residual static stresses are created and their magnitude depends on the misfit amplitude (15), suggesting that these residual static stresses could change the behavior of the screw joint stability of multiple-unit when compared with simpleunit implant dentures. There is very limited information about the effects of retightening some time after settling of the prosthetic screws on the joint stability in multiunit dentures.

The aim of this in vitro study was to evaluate the effect of retightening the screws $10 \mathrm{~min}$ after the initial tightening torque (retorque) on the loosening torque of prosthetic screws at 2 levels of fit (passive fit and vertical misfit) in mandibular implant-supported dentures. The hypothesis tested was that the application of the retorque increases loosening torque of the prosthetic screws.

\section{MATERIAL AND METHODS}

\section{Experimental Design}

Ten mandibular implant-supported dentures were fabricated and then 20 cast models ( 10 with passive fit and 10 with misfit) were prepared using the prosthetic structures. Two prosthetic screw tightening techniques were tested on the loosening torque for 2 different levels of fit (passive fit and misfit) of the dentures. Forty screw sets made of titanium alloy and 40 of gold alloy (Conexão Sistemas de Prótese Ltda., São Paulo, SP, Brazil) (Table 1) were evaluated separately and were assigned to 4 groups $(n=10)$ according to the following conditions: without retorque/passive fit; without retorque/misfit; with retorque application/passive fit; and with retorque application/misfit.

\section{Prosthetic Structure Fabrication}

A metal matrix was fabricated and 5 conical abutment analogs (4.1 mm Micro-unit; Conexão Sistemas de Prótese Ltda.) were fixed to it with transversal screws. The abutment analog disposition (A, B, C, D and E) used in this study simulates a clinical situation of 5 implants placed between mental foramens, arranged in an arch mode, with 10-mm inter-implant spaces (Fig. 1). A master cast was then fabricated using a splinted impression technique to allow the waxing of ten pros-

Table 1. Prosthetic screws used in the study.

\begin{tabular}{lc}
\hline Prosthetic screw & Alloy composition* \\
\hline Gold alloy & $68.5 \% \mathrm{Au}, 8.5 \% \mathrm{Ag}, \mathrm{Cu} \% 23, \leq$ \\
& $0.0014 \% \mathrm{~Pb}, \mathrm{Zn}, \mathrm{Ni}, \mathrm{Cd}, \mathrm{Co}$, and $\mathrm{Pd}$ \\
Titanium alloy & $90 \% \mathrm{Ti}, 6 \% \mathrm{Al}$, and $4 \% \mathrm{~V}$ \\
\hline
\end{tabular}

*Alloy composition percentages obtained from the manufacturers.

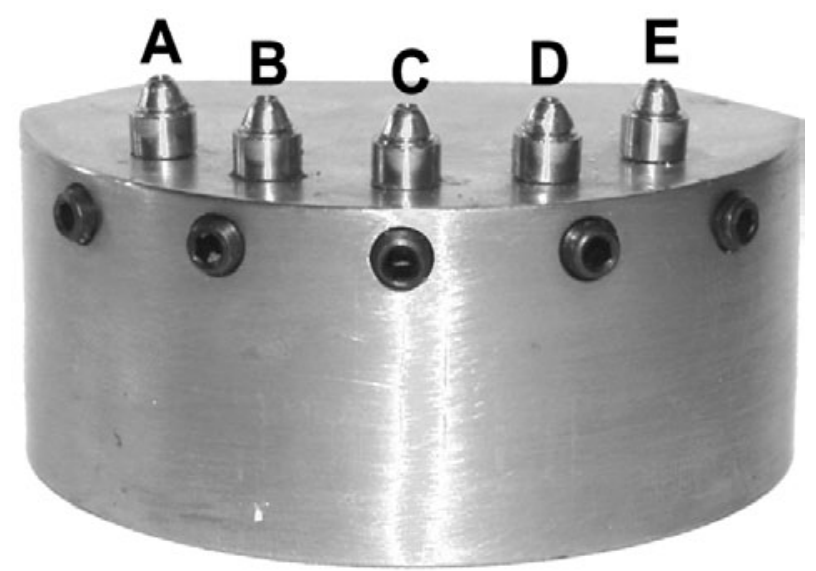

Figure 1. Metal matrix and abutment analog disposition. 
thetic frameworks with calcinable cylinders (Conexão Sistemas de Prótese Ltda.) and bar wax cylinders (Wax wire 4.0; Dentaurum, Pforzheim, Germany). The free ends were standardized at a $10-\mathrm{mm}$ distal extension. The frameworks were then cast in cobalt-chromium alloy (Dentaurum) using the lost-wax casting technique. Heat-polymerized acrylic resin (Clássico, São Paulo, SP, Brazil) and artificial teeth (Vipi Plus; VIPI, Pirassununga, SP, Brazil) were used as veneering material.

\section{Fit Level Simulation}

Twenty cast models ( 10 for passive fit and 10 for misfit) were fabricated using the prosthetic structures, maintaining the abutment analog positions to simulate the 2 levels of fit tested. For the passive fit, no rings were used between the abutment analogs ( $4.1 \mathrm{~mm}$ Micro-unit; Sistemas de Prótese Ltda.) and framework cylinders of the prosthesis. For the misfit, 3 steel rings of different thicknesses $(100,200$ and $300 \mu \mathrm{m}$, one for each analog, respectively) were used between 3 of the framework cylinders of the prosthesis and abutment analogs $(\mathrm{C}$, $\mathrm{D}$ and $\mathrm{E})$; the other abutment analogs (A and $\mathrm{B})$ were screwed directly to the framework cylinders. Assembly of the components with regard to the levels of fit is shown in Figure 2. All these sets were invested in the stone cast (type VI Herostone; Vigodent, Rio de Janeiro, RJ, Brazil) using a delineator. The rings were added to create a vertical prosthetic misfit of approximately 250 $\mu \mathrm{m}$. The one-screw test was then used to quantify the 2 levels of fit tested (Fig. 3).

\section{Fit Evaluation (One-Screw Test)}

An optic microscope (VMM-150; Walter Uhl, Asslar, Germany) was used to measure the vertical misfit at $120 \times$ magnification. The technique used to measure the vertical misfit was based on the one-screw test protocol (16). This technique involved one titanium screw (Conexão Sistemas de Prótese Ltda.) tightened to 10 Ncm onto the abutment " $A$ " using a manual torque meter

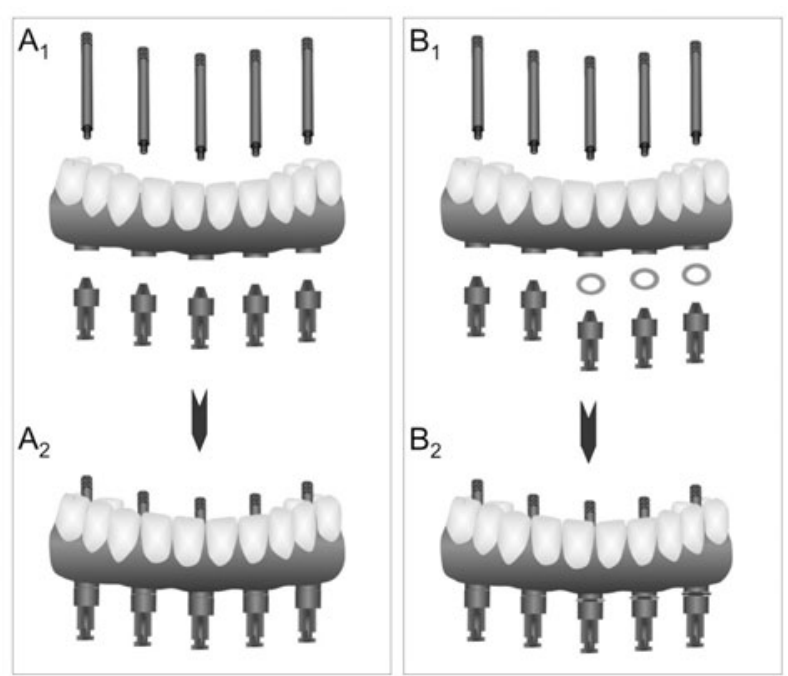

Figure 2. Schematic illustrations of assembling the components to simulate the different levels of fit: $\left(\mathrm{A}_{1}\right)$ components in passive fit; $\left(A_{2}\right)$ components assembled in passive fit; $\left(B_{1}\right)$ components in misfit; $\left(B_{2}\right)$ components assembled in misfit with rings $( \pm 100$, 200 and $300 \mu \mathrm{m}$ thickness) inserted between cylinders and abutment analogs.
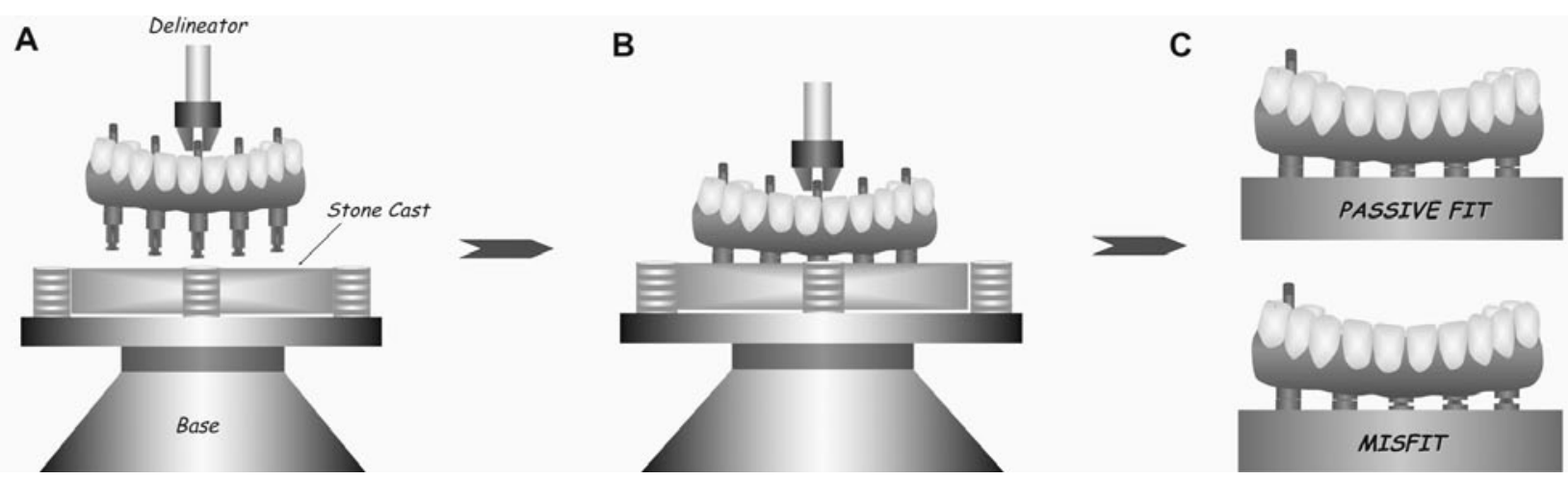

Figure 3. Schematic illustrations of fabrication of the cast models: (A) set assembled; (B) abutment analogs invested in stone cast; (C) two fit conditions in the one-screw test. 
(Conexão Sistemas de Prótese Ltda.). Vertical misfits between platform abutment analogs and the inferior border of the denture framework cylinders were then measured, 3 times, considering the buccal and lingual faces of the abutments "C" and "E". Next, the titanium screw was loosened and replaced with another screw tightened to $10 \mathrm{Ncm}$ onto abutment "E", and the vertical misfit of the abutments " $C$ " and " $\mathrm{A}$ " were evaluated as was done previously.

A total of 24 vertical misfit values were obtained for each prosthetic structure and its cast model, and then the mean of these values was calculated to determine the misfit of the prosthesis. The mean values and standard deviations (SD) concerning the vertical misfit were: 51 $\mu \mathrm{m}( \pm 23)$ for passive fit; and $264 \mu \mathrm{m}( \pm 78)$ for misfit. The Student's t-test showed statistical significant difference between the levels of fit $(p<0.001)$.

\section{Loosening Torque Evaluation}

The loosening torque was evaluated using a digital torque meter with a $0.1-\mathrm{Ncm}$ precision (TQ8800; Lutron, Taipei, Taiwan), involving 40 screw sets (5 screws in each set) of titanium alloy and 40 screw sets of gold alloy. One calibrated researcher performed the loosening torque. The cast models were fixed to a laboratory desk using a metal peg, and the prosthetic screws were tightened in the sequence B, D, C, A and E. Two tightening techniques were tested: 1 ) only the $10-\mathrm{Ncm}$ initial tightening torque was applied; and 2) $10-\mathrm{Ncm}$ initial tightening torque was applied to the screws, 10 min later the screws were retightened to $10 \mathrm{Ncm}$.

The loosening torque was evaluated $24 \mathrm{~h}$ after the initial tightening torque following the same tightening sequence (B, D, C, A and E). The loosening torque of a determined prosthetic screw was evaluated, and this screw was again tightened $(10 \mathrm{Ncm})$ to its abutment, thus the loosening torque of the other prosthetic screws was measured with all the other screws tightened. The mean loosening torque values $(\mathrm{Ncm})$ of the screw sets were submitted to two-way (retorque $\mathrm{x}$ fit) ANOVA followed by Tukey's test $(\alpha=0.05)$, separately for each screw material.

\section{RESULTS}

The results for gold screws are shown in Table 2, and for titanium screws, in Table 3. For gold screws, two-way ANOVA showed that the factors 'retorque' and 'fit' do not significantly interfere with loosening torque ( $p=0.085$ and $p=0.350$, respectively). In addition, there is also no statistically significant interaction between 'retorque' and 'fit' $(\mathrm{p}=0.850)$.

For titanium screws, the screws used in dentures with misfit presented lower loosening torque than those used in dentures with passive fit, when retorque was not applied ( $\mathrm{p}=0.005)$. On the other hand, this misfit had no significant influence on the loosening torque, when the retorque was applied on the titanium screws ( $\mathrm{p}=0.857$ ). Retorque did not significantly interfere on the loosening torque when the titanium screws were used in dentures with passive fit $(\mathrm{p}=0.459)$. However, the retorque significantly increased the loosening torque when these screws were used in dentures with misfit $(\mathrm{p}=0.001)$.

\section{DISCUSSION}

In the present study, as expected, the results of all groups showed that irrespective of the screw material used the torque necessary to remove the prosthetic

Table 2. Means (standard deviations) of loosening torque ( $\mathrm{Ncm})$ for gold screws.

\begin{tabular}{lcc}
\hline \multirow{2}{*}{ Fit } & \multicolumn{2}{c}{ Retorque } \\
\cline { 2 - 3 } & No & Yes \\
\hline Passivity fit & $5.42(0.99)^{\mathbf{A}, \mathbf{a}}$ & $5.97(1.00)^{\mathbf{A}, \mathbf{a}}$ \\
Misfit & $5.03(1.33)^{\mathbf{A}, \mathbf{a}}$ & $5.71(1.02)^{\mathbf{A}, \mathbf{a}}$ \\
\hline
\end{tabular}

Means followed by different uppercase letters in the same line, and lowercase letters in the same column were significantly different at $\mathrm{p}<0.05$.

Table 3. Means (standard deviations) of loosening torque ( $\mathrm{Ncm})$ for titanium screws.

\begin{tabular}{lcc}
\hline \multirow{2}{*}{ Fit } & \multicolumn{2}{c}{ Retorque } \\
\cline { 2 - 3 } & No & Yes \\
\hline Passivity fit & $6.99(1.03)^{\mathbf{A , a}}$ & $7.33(0.79)^{\mathbf{A , a}}$ \\
Misfit & $5.65(1.18)^{\mathbf{B , b}}$ & $7.24(1.00)^{\mathbf{A , a}}$ \\
\hline
\end{tabular}

Means followed by different uppercase letters in the same line, and lowercase letters in the same column were significantly different at $\mathrm{p}<0.05$. 
screws was lower than the initial tightening torque. This is in agreement with other studies $(6,17)$.

Perfectly fitting multi-unit implant dentures have been a theoretical ideal, but hardly achievable clinically. The conventional dental laboratory techniques do not allow a framework to be fabricated without the presence of misfits. The errors are mostly due to the volumetric inconsistency and linear expansion of the materials used in framework fabrication, which include impression material, gypsum products, waxes, investments, and casting metal; in other words, potential distortion can be created at any step of the fabrication process (18). Based on logical deduction or personal experience, levels of acceptable fit between 10 and $150 \mu \mathrm{m}$ have been proposed. In 1983, Branemark proposed that this should be at the level of $10 \mu \mathrm{m}$ to enable bone maturation and remodeling in response to occlusal loads (19). In 1991, Jemt defined passive fit as the level that did not cause any long-term clinical complications and suggested misfits smaller than $150 \mu \mathrm{m}$ were acceptable (4). The mean value of simulated vertical misfit was $51( \pm 23)$ $\mu \mathrm{m}$ for dentures with passive fit, among those referred to as clinically acceptable. While the mean value of the simulated vertical misfit was $263( \pm 78) \mu \mathrm{m}$ for dentures, above values referred to as clinically acceptable.

The dentures with higher misfit values than those clinically acceptable reduced the loosening torque of titanium screws when using the conventional screw tightening technique (without retorque application). The main cause of this result probably was the generation of residual stresses in the implant-retained system. When a certain torque is applied to the screws used to retain multi-unit dentures, the ideal environment would be only the force that 2 joint members exert on each other and tension on the screw that was created; in the other words, the clamping force and preload (13). Due to the ankylotic nature of osseointegrated implants, any stress (static or dynamic) occurring in the system will be transmitted to its components. When a prosthesis framework with lack of passivity is harshly connected to the osseointegrated implants, extra shearing and tension stresses will be created, acting on the screw joints (1). Therefore, higher levels of misfit increase the residual static stresses, decreasing the screw joint stability for titanium screws.

The tested hypothesis was partially confirmed; once the retorque applied $10 \mathrm{~min}$ after the initial tightening torque increased the loosening torque for the titanium screws in the dentures with misfit. This finding can be explained by the hypothesis that the screw threads cannot be machined perfectly smooth (20); part of the torque applied to the screws could have been lost to smooth the irregularities in the screw threads and abutment threads, therefore the application of a retightening torque once again after embedment relaxation or settling acted to regain preload and to increase contact area between the threads. However, the retorque did not show a significant improvement in the joint stability of titanium screws in dentures with passive fit. The greater amount of residual static stresses in dentures with misfit above the clinically acceptable values could have increased the levels of settling and plastic deformation, particularly in the titanium screws, to close the misfits. Siamos et al. (11) evaluating the effect of retorque on premachined abutment screws before and after mechanical cycling, advocated that retightening abutment screws 10 min after initial torque application should be performed routinely during abutment-implant connections.

The tested misfits did not affect the loosening torque of gold screws and the retorque application showed no significant improvement. This result could be explained by higher malleability and ductibility of the gold screws, so that the residual stresses and the settling were able to decrease the effect on the joint stability, however, there are no relevant studies stating that gold screw are more stable than titanium screws in multiple dentures.

Based on these findings, it can be suggested that retorque appears to show a good possibility of increasing the joint stability of titanium screws, and this procedure should be performed routinely during the titanium screw tightening in multiple prostheses. However, gold screw does not need additional tightening to increase the joint stability. Further investigation is fundamental to allow evaluating the effect of the retorque application on the behavior of the joint stability under cyclic loading.

\section{RESUMO}

Este estudo avaliou a influência do retorque no Ta dos parafusos protéticos em próteses implantossuportadas com diferentes níveis de adaptação. Foram confeccionadas 10 próteses mandibulares implantossuportadas. Vinte modelos de gesso foram fabricados utilizando as estruturas protéticas para criar os 2 níveis de adaptação: adaptação passiva (AP) e desajuste (D). Foram avaliadas 2 técnicas de aperto do parafuso: inicial torque (T1); e inicial torque e retorque após $10 \mathrm{~min}$ (T2). Foram usados parafusos de ouro e titânio, resultando em 4 grupos para cada material 
do parafuso: AP/T1, AP/T2, D/T1, D/T2. O Ta foi mensurado $24 \mathrm{~h}$ após o torque de aperto utilizando torquímetro digital. Os resultados foram analisados pela ANOVA (2 fatores) e teste de Tukey $(\alpha=0,05)$, separadamente para cada material dos parafusos. Para os parafusos de titânio, não foi encontrada diferença estatística significante entre AP/T1 e AP/T2, ou AP/T2 e D/T2; porém, diferença significante foi encontrada entre AP/T1 e D/ T1, ou D/T1 e D/T2. Onde, D reduziu a Ta utilizando T1; e T2 aumentou o Ta para D. Retorque e adaptação não apresentaram influência significante no Ta dos parafusos de ouro. A aplicação do retorque tornou insignificante o efeito do desajuste no Ta dos parafusos de titânio, sugerindo que este procedimento deveria ser usado rotineiramente durante os parafusos protéticos de titânio em próteses múltiplas.

\section{ACKNOWLEDGEMENTS}

This research was supported by grants $07 / 55352-8 R$ the São Paulo State Research Foundation (FAPESP).

\section{REFERENCES}

1. Skalak R. Biomechanical considerations in osseointegrated prostheses. J Prosthet Dent 1983;49:843-848.

2. Jemt T, Book K. Prosthesis misfit and marginal bone loss in edentulous implant patients. Int J Oral Maxillofac Implants 1996;11:620-625.

3. Carr AB, Gerard DA, Larsen PE. The response of bone in primates around unloaded dental implants supporting prostheses with different levels of fit. J Prosthet Dent 1996;76:500-509.

4. Jemt T. Failures and complications in 391 consecutively inserted fixed prostheses supported by Branemark implants in edentulous jaws: a study of treatment from the time of prosthesis placement to the first annual checkup. Int J Oral Maxillofac Implants 1991;6:270-276.

5. Behr M, Lang R, Leibrock A, Rosentritt M, Handel G. Complication rate with prosthodontic reconstructions on ITI and IMZ dental implants. Internationales Team fur Implantologie. Clin Oral Implants Res 1998;9:51-58.

6. al-Turki LE, Chai J, Lautenschlager EP, Hutten MC. Changes in prosthetic screw stability because of misfit of implant-supported prostheses. Int J Prosthodont 2002;15:38-42.
7. Gross M, Kozak D, Laufer BZ, Weiss EI. Manual closing torque in five implant abutment systems: an in vitro comparative study. J Prosthet Dent 1999;81:574-578.

8. McGlumphy EA. Keeping implant screws tight: the solution. J Dent Symp 1993;1:20-23.

9. Stüker RA, Teixeira ER, Beck JCP, Costa NP. Preload and torque removal evaluation of three different abutment screws for single standing implant restorations. J Appl Oral Sci 2007;16:55-58.

10. Jorneus L, Jemt T, Carlsson L. Loads and designs of screw joints for single crowns supported by osseointegrated implants. Int J Ora Maxillofac Implants 1992;7:353-359.

11. Siamos G, Winkler S, Boberick KG. Relationship between implant preload and screw loosening on implant-supported prostheses. J Oral Implantol 2002;28:67-73.

12. Weiss EI, Kozak D, Gross MD. Effect of repeated closures on opening torque values in seven abutment-implant systems. J Prosthet Dent 2000;84:194-199.

13. Bickford JH. Introduction to the design and behavior of bolted joints: non-gasketed joints. 4th ed. Boca Ration: CRC Press; 2007.

14. Barbosa GA, Simamoto Junior PC, Fernandes Neto AJ, de Mattos Mda G, Neves FD. Prosthetic laboratory influence on the vertical misfit at the implant/UCLA abutment interface. Braz Dent J 2007;18:139-143.

15. Millington ND, Leung T. Inaccurate fit of implant superstructures. Part 1: Stresses generated on the superstructure relative to the size of fit discrepancy. Int J Prosthodont 1995;8:511-516.

16. Tan KB, Rubenstein JE, Nicholls JI, Yuodelis RA. Three-dimensional analysis of the casting accuracy of one-piece, osseointegrated implant-retained prostheses. Int J Prosthodont 1993;6:346-363.

17. Barbosa GA, Bernardes SR, das Neves FD, Fernandes Neto AJ, de Mattos Mda G, Ribeiro RF. Relation between implant/abutment vertical misfit and torque loss of abutment screws. Braz Dent J 2008; 19:358-363.

18. Romero GG, Engelmeier R, Powers JM, Canterbury AA. Accuracy of three corrective techniques for implant bar fabrication. J Prosthet Dent 2000;84:602-607.

19. Branemark PI. Osseointegration and its experimental background. J Prosthet Dent 1983;50:399-410.

20. Dixon DL, Breeding LC, Sadler JP, McKay ML. Comparison of screw loosening, rotation, and deflection among three implant designs. J Prosthet Dent 1995;74:270-278.

Accepted October 30, 2009 